\title{
KUALITAS FISIK DAN KIMIA TELUR PINDANG MENGGUNAKAN DAUN \\ JAMBU BIJI (Psidium guajava L) SERTA GARAM NaCl DENGAN KONSENTRASI BERBEDA
}

\author{
Sasmita Nusi, Merri D Rotinsulu*, Moureen Tamasoleng, Rahmawaty Hadju
}

Fakultas Peternakan Universitas Sam Ratulangi Manado, 95115

\begin{abstract}
ABSTRAK
Penelitian ini bertujuan untuk mengetahui kualitas fisik dan kimia telur pindang menggunakan daun jambu biji (Psidium guajava L) serta garam $\mathrm{NaCl}$ dengan konsentrasi berbeda. Materi yang digunakan adalah telur ayam ras, daun jambu biji, garam $\mathrm{NaCl}$. Penelitian ini menggunakan Rancangan Acak Lengkap (RAL) dengan pola faktorial 3x3 dengan ulangan sebanyak 3 kali. Faktor A terdiri dari daun jambu biji dengan 3 level yakni $2,5 \%, 5 \%$, dan 7,5\%. Faktor B terdiri dari garam $\mathrm{NaCl}$ dengan 3 level yakni $2,5 \%$, $5 \%$, dan $7,5 \%$. Hasil analisis ragam menunjukkan bahwa pemberian daun jambu biji dan garam $\mathrm{NaCl}$ berbeda sangat nyata $(\mathrm{P}<0,01)$ terhadap selisih berat telur, kadar air, kekuatan gel, tetapi tidak berbeda nyata $(\mathrm{P}>0,01)$ terhadap $\mathrm{pH}$. Berdasarkan dari hasil penelitian diatas maka disimpulkan bahwa yang terbaik untuk sifat fisik dan kimia telur pindang yaitu perlakuan dengan $7,5 \%$ daun jambu biji (Psidium guanjava L) dan $7,5 \%$ garam $\mathrm{NaCl}$.
\end{abstract}

Kata Kunci : Telur Pindang, Daun Jambu Biji, Garam NaCl, Sifat Fisik-Kimia

\section{ABSTRACT}

PHYSICAL AND CHEMICAL QUALITY OF PINDANG EGGS USING GUAVA LEAVES (PSIDIUM GUAJAVA L) AND NACL SALT WITH DIFFERENT CONCENTRATIONS. This study aims to determine the physical and chemical quality of pindang eggs using guava leaves and $\mathrm{NaCl}$ salt with different concentrations. The material used was egg, guava leaves, $\mathrm{NaCl}$ salt. This research used complete randomized design (CRD) with a factorial of $3 \times 3$ with 3 times replicated. Factor A consists of guava leaves with 3 levels namely $2.5 \%, 5 \%$, and $7.5 \%$. Factor B consists of $\mathrm{NaCl}$ salt with 3 levels namely $2.5 \%, 5 \%$, and $7.5 \%$. Analysis of the variance showed that the distribution of guava leaves and $\mathrm{NaCl}$ salt was significant $(\mathrm{P}<0.01)$ on egg weight, moisture, gel forces, and non significant $(\mathrm{P}>0.01)$ on $\mathrm{pH}$. Based on the results of such studies, it can be concluded that the best for the physical and chemical properties of the pindang egg was treatment of $7.5 \%$ of guava leaves and $7.5 \%$ of the $\mathrm{NaCl}$ salt.

Keywords: Pindang Eggs, Guava Leaves, $\mathrm{NaCl}$ Salt, Physical-Chemical Properties

\section{PENDAHULUAN}

Telur merupakan bahan pangan hasil ternak unggas yang memiliki sumber protein hewani yang memiliki rasa lezat, *korespondensi (corresponding author)

Email:merrirot@gmail.com 
mudah dicerna dan bergizi tinggi. (Agustina et al., 2013). Berdasarkan data statistik, konsumsi telur ayam ras di Indonesia bertumbuh sebesar $1,61 \%$ dalam rentang waktu tahun 2009-2013 (BPS, 2014). Hal ini karena telur ayam ras khususnya merupakan komoditas yang relatif terjangkau dan memiliki gizi yang tinggi sehingga diminati oleh masyarakat (Suharyanto et al., 2016). Di masyarakat telur ayam ras dapat disiapkan dalam berbagai bentuk olahan, harganya relatif murah, sangat mudah diperoleh dan selalu tersedia setiap saat (Nasikin et al., 2015).

Telur mengandung asam amino esensial lengkap sehingga telur dijadikan patokan dalam menentukan mutu protein berbagai bahan pangan (Richard et al., 2014). Namun telur mudah mengalami penurunan kualitas yang disebabkan oleh kerusakan secara fisik, kimia dan mikrobiologis. Terjadinya kerusakan fisik pada telur selama penyimpanan akan mempercepat kontaminasi mikroorganisme dan terjadinya perubahan kimia. Sehingga perlu penganekaragaman olahan telur, seperti pengolahan tepung telur, abon telur, telur asin, dan telur pindang. Pengolahan telur yang praktis dan pengolahannya tidak sulit adalah telur pindang.

Menurut Citra (2014) bahwa perebusan telur pindang dibagi menjadi tiga perlakuan, yaitu perebusan tanpa daun jambu biji dengan peretakan kerabang telur, perebusan dengan daun jambu biji dengan peretakan kerabang, dan perebusan dengan daun jambu biji tanpa peretakan kerabang. Didapatkan hasil perebusan terbaik diperoleh dari perlakuan perebusan dengan daun jambu biji yang kerabang telurnya diretak.

Pada penelitian Nastiti (2007), pengolahan telur pindang dilakukan dengan cara perebusan menggunakan 3 perlakuan yaitu 1 jam, 2 jam, dan 3 jam. Hasil perebusan terbaik diperoleh pada perlakuan perebusan selama 2 jam.

Pada penelitian Dewi et al. (2013), hasil ekstraksi dan karakterisasi zat warna alami dari daun jambu biji (Psidium Guajava L.) menunjukkan bahwa daun jambu biji mengandung antosianin seperti cyanidin-3- sophoroside dan cyanidin3glucoside serta mengandung flavan-3,4diols yang tergolong senyawa tannin berupa pigmen kuning sampai coklat. Senyawa tersebut berperan penting pada pewarnaan daun jambu biji.

Telur pindang merupakan pengolahan kombinasi penambahan daun jambu biji (Psidium guajava L), penggaraman dan perebusan. Garam $\mathrm{NaCl}$ ketersediaan banyak dan mudah didapat yang berfungsi sebagai pengawet, meningkatkan kualitas organoleptik telur, mendenaturasikan protein telur (Nuruzzakiah et al., 2016). Selain itu, daun 
jambu biji berperan dalam pengolahan dan pengawetan telur pindang (Nastiti, 2007). Pada daun jambu biji terdapat senyawa tanin antara 3,25-8,98\%. Tanin yang bersifat menyamak kulit telur dapat memperpanjang umur simpan telur. Tanin akan menyebabkan protein dipermukaan kulit telur menggumpal dan menutupi poripori, mencegah terjadinya penguapan, mencegah hilangnya $\mathrm{CO} 2$, dan mencegah masuknya mikroorganisme sehingga telur menjadi lebih awet (Ernawati et al., 2019). Samaludin et al. (2019) menyatakan bahwa daun jambu biji dapat meningkatkan kualitas organoleptik telur pindang dan dapat mendenaturasikan protein telur yang bisa mempengaruhi kualitas fisik dan kimia telur pindang

Proses pembuatan telur pindang telah banyak dilakukan dengan menggunakan daun jambu biji, menggunakan garam $\mathrm{NaCl}$, namun belum ada penelitian mengenai kombinasi keduanya. Berdasarkan latar belakang hal tersebut, maka dilakukan penelitian mengenai kualitas fisik telur pindang yaitu selisih berat telur, kekuatan gel, $\mathrm{pH}$ dan kualitas kimia telur pindang yaitu kadar air telur pindang, dengan menggunakan kombinasi daun jambu biji serta garam $\mathrm{NaCl}$ dengan konsentrasi yang berbeda dengan tujuan untuk mengetahui sejauh mana pengaruh kombinasi daun jambu biji dan garam $\mathrm{NaCl}$ terhadap kualitas sifat fisik dan kimia telur pindang.

\section{MATERI DAN METODE PENELITIAN}

\section{Waktu dan Tempat Penelitian}

Penelitian ini telah dilaksanakan di Laboratorium Teknologi Hasil Ternak Fakultas Peternakan, Universitas Sam Ratulangi Manado.

\begin{abstract}
Alat dan Bahan
Peralatan yang digunakan dalam penelitian ini adalah timbangan analitik, waterbath, thermometer, plastik, $\mathrm{pH}$ meter, gelas ukur, batang silinder, oven, Desikator.

Bahan yang digunakan dalam penelitian ini adalah telur ayam ras sebanyak 81 butir dengan berat 63-70 g, daun jambu biji (Psidium guajava L.) yang masih segar, garam $\mathrm{NaCl}$ dan aquades.
\end{abstract}

\section{Metode Penelitian}

Penelitian ini akan dilaksanakan melalui suatu percobaan dengan menggunakan rancangan acak lengkap (RAL) dengan pola faktorial $3 \times 3$ (Steel dan Torrie, 1991) dengan ulangan sebanyak 3 kali.

Dalam penelitian ini yang dipakai sebagai perlakuan ialah konsentrasi daun jambu biji sebagai faktor $\mathrm{A}$, dan konsentrasi garam $\mathrm{NaCl}$ sebagai faktor $\mathrm{B}$, 
selanjutnya rumusan perlakuan diatur sebagai berikut:

Faktor A=Daun jambu biji dengan konsentrasi (b/v) :

$\mathrm{A}_{1}=2,5 \%$

$\mathrm{A}_{2}=5 \%$

$\mathrm{A}_{3}=7,5 \%$

Faktor $\mathrm{B}=\mathrm{Garam} \mathrm{NaCl}$ dengan konsentrasi $(\mathrm{b} / \mathrm{v})$ :

$\mathrm{B}_{1}=2,5 \%$

$\mathrm{B}_{2}=5 \%$

$\mathrm{B}_{3}=7,5 \%$

\section{Prosedur Penelitian}

Telur ditimbang terlebih dahulu untuk mendapatkan berat telur awal. Kemudian semua bahan (telur, daun jambu biji) dicuci terlebih dahulu. Telur, daun jambu biji 2,5\%, 5\%, 7,5\% b/v, dan garam $2,5 \%, 5 \%, 7,5 \% \mathrm{~b} / \mathrm{v}$ dimasukkan ke dalam plastik dan ditambahkan air menjadi 1 liter. Selanjutnya direbus di dalam waterbath (Suhu $\pm 90^{\circ} \mathrm{C}$ ) selama 10 menit dan peretakan kerabang telur dilakukan, kemudian direbus kembali selama 1 jam 50 menit. Selanjutnya telur pindang diangkat dan didinginkan, kemudian dilakukan uji selisih berat telur, kadar air, kekuatan gel dan $\mathrm{pH}$.

\section{Variabel yang diteliti}

Variabel yang diamati pada penelitian ini adalah :

Selisih berat telur. Perhitungan selisih berat telur dapat dihitung berdasarkan selisih berat telur awal dengan berat akhir penelitian (Titirloloby, 2006).

Kadar Air. Adapun metode penentuan kadar air dengan pengeringan menurut AOAC (2005) yaitu: Sampel sebanyak 3-5 g ditimbang dan dimasukan kedalam cawan yang telah dipanaskan dan diketahui bobotnya. Kemudian sampel dan cawan dipanaskan dalam oven suhu $105^{\circ} \mathrm{C}$ selama 6 jam. Cawan dan sampel didinginkan di dalam desikator dan ditimbang, kemudian dipanaskan kembali sampai diperoleh bobot konstan.

$$
\frac{B-C}{B-A} \times 100 \%
$$

Dimana :

$\mathrm{A}=$ Berat cawan porselin

$\mathrm{B}=$ Berat cawan dengan sampel sebelum dipanaskan

$\mathrm{C}=$ Berat cawan dengan sampel setelah dipanaskan

Kekuatan Gel. Telur yang sudah direbus didinginkan, kemudian sampel putih telur dengan panjang $3 \mathrm{~cm}$ dan lebar $3 \mathrm{~cm}$ diletakan diatas timbangan, selanjutnya batang silinder ditekan dengan tangan diatas permukaan putih telur sampai pecah dan beratnya dicatat. Kekuatan gel adalah berat dibagi dengan luas penampang silinder (Umar, 2017) dengan rumus sebagai berikut:

Kekuatan Gel $\left(\mathrm{g} / \mathrm{cm}^{2}\right)$ 


$$
=\frac{\text { Berat Putih Telur }}{\text { Luas Penampang Silinder }}
$$

Nilai pH. Pengukuran $\mathrm{pH}$ menurut AOAC (2005) dalam dilakukan sebagai berikut: Derajat keasaman telur diukur dengan menggunakan $\mathrm{pH}$ meter, dan dikalibrasi dengan larutan buffer dengan nilai $\mathrm{pH} 4$ dan 7. Sampel disiapkan sebanyak 5 gram. Kemudian ditambah aquades $20 \mathrm{ml}$, Setelah itu sampel di aduk selama lima menit, $\mathrm{pH}$-meter dicelupkan ke dalam sampel kira-kira 2-4 cm. nilai $\mathrm{pH}$ diperoleh dengan membaca skala yang ditunjukan oleh jarum penunjuk.

\section{HASIL DAN PEMBAHASAN}

\section{Selisih Berat Telur}

Hasil analisis sidik ragam menunjukkan bahwa interaksi daun jambu biji dan garam $\mathrm{NaCl}$ memberikan pengaruh yang berbeda sangat nyata $(\mathrm{P}<0,01)$ terhadap selisih berat telur pindang.
Berdasarkan hasil uji BNJ untuk ragam interaksi menunjukkan bahwa nilai selisih berat telur dengan menggunakan daun jambu biji 2,5\% + 2,5\% garam $\mathrm{NaCl}$ berbeda sangat nyata $(\mathrm{P}<0,01)$ dengan daun jambu biji $2,5 \%+5 \%$ garam $\mathrm{NaCl}$ dan daun jambu biji 2,5\% + 7,5\% garam $\mathrm{NaCl}$. Kemudian daun jambu biji 2,5\% + 5\% garam $\mathrm{NaCl}$ berbeda tidak nyata $(\mathrm{P}>0,01)$ dengan $2,5 \%$ daun jambu biji $+7,5 \%$ garam $\mathrm{NaCl}$. Selanjutnya daun jambu biji $5 \%+$ 2,5\% garam $\mathrm{NaCl}$ berbeda tidak nyata $(\mathrm{P}>0,01)$ dengan daun jambu biji 5\% $+5 \%$ garam $\mathrm{NaCl}$, tetapi berbeda nyata $(\mathrm{P}<0,01)$ dengan daun jambu biji $5 \%+7,5 \%$ garam $\mathrm{NaCl}$. Lebih lanjut daun jambu biji 7,5\% + 2,5\% garam $\mathrm{NaCl}$ berbeda tidak nyata (P>0,01) dengan daun jambu biji 7,5\% + $5 \%$ garam $\mathrm{NaCl}$. Kemudian daun jambu biji $7,5 \%+5 \%$ garam $\mathrm{NaCl}$ berbeda tidak nyata ( $\mathrm{P}>0,01)$ dengan daun jambu biji $7,5 \%$ $+7,5 \%$ garam $\mathrm{NaCl}$.

Tabel 1. Rataan Selisih Berat (g) Telur Pindang Yang Menggunakan Daun Jambu Biji (Psidium guanjava L) serta Garam $\mathrm{NaCl}$ Dengan Konsentrasi

\begin{tabular}{cllll}
\hline \multirow{2}{*}{ Perlakuan } & \multicolumn{3}{c}{ Garam NaCl } \\
\cline { 2 - 5 } & $2,5 \%$ & $5 \%$ & $7,5 \%$ \\
\hline \multirow{2}{*}{ Daun Jambu } & $2,5 \%$ & $0,49^{\mathrm{d}}$ & $0,77^{\mathrm{bc}}$ & $0,94^{\mathrm{b}}$ \\
biji & $5 \%$ & $0,60^{\mathrm{c}}$ & $0,65^{\mathrm{c}}$ & $1,60^{\mathrm{a}}$ \\
& $7,5 \%$ & $0,41^{\mathrm{d}}$ & $0,59^{\mathrm{cd}}$ & $0,61^{\mathrm{c}}$ \\
\hline
\end{tabular}

Ket: Superskrip yang berbeda pada setiap kombinasi perlakuan menunjukkan perbedaan yang nyata $(\mathrm{P}<0,01)$ 
Nilai selisih berat telur yang paling baik yaitu yang menggunakan daun jambu biji $5 \%+7,5 \%$ garam $\mathrm{NaCl}(1,60 \mathrm{~g})$ yang ditunjukkan oleh nilai selisih berat telur yang besar. Semakin banyak garam dan tanin terikat maka semakin besar selisih berat telur yang didapat. Selisih berat telur yang besar disebabkan terjadinya pembentukan koagulasi telur yang lebih kuat dan kompak. Komposisi garam 7,5\% dapat membuka struktur protein dari telur yang menyebabkan tanin dari daun jambu biji sebanyak 5\% terikat pada protein tersebut selama pemindangan. Samaludin et al. (2019) menyatakan bahwa tanin yang terkandung dalam daun jambu biji menyebabkan protein di permukaan telur terkoagulasi (menggumpal) membentuk senyawa kompleks yang stabil dan mempunyai kemampuan untuk mengikat protein. Sehingga kandungan tanin yang terdapat didalam daun jambu biji terserap kedalam telur selama perebusan. Begitupun dengan garam, penambahan garam juga berpengaruh pada struktur protein telur (Sukma et al., 2012).

\section{Kadar Air}

Hasil analisis sidik ragam menunjukkan bahwa interaksi daun jambu biji dan garam $\mathrm{NaCl}$ memberikan pengaruh yang berbeda sangat nyata $(\mathrm{P}<0,01)$ terhadap kadar air telur pindang.

Berdasarkan hasil uji BNJ untuk ragam interaksi menunjukkan bahwa nilai kadar air dengan menggunakan daun jambu biji $2,5 \%+2,5 \%$ garam $\mathrm{NaCl}$ berbeda sangat nyata $(\mathrm{P}<0,01)$ dengan daun jambu biji 2,5\% + 5\% garam $\mathrm{NaCl}$. Daun jambu biji 2,5\% +5\% garam $\mathrm{NaCl}$ berbeda tidak nyata $(\mathrm{P}>0,01)$ dengan daun jambu biji $2,5 \%+7,5 \%$ garam $\mathrm{NaCl}$. Kemudian daun jambu biji $5 \%+2,5 \%$ garam $\mathrm{NaCl}$ berbeda tidak nyata $(\mathrm{P}>0,01)$ dengan $5 \%$ daun jambu biji $+5 \%$ garam $\mathrm{NaCl}$, tetapi berbeda sangat nyata $(\mathrm{P}>0,01)$ dengan daun jambu biji $5 \%+7,5 \%$ garam $\mathrm{NaCl}$. Selanjutnya

Tabel 2. Rataan Kadar Air (\%) Telur Pindang Yang Menggunakan Daun Jambu Biji (Psidium guanjava $L$ ) serta Garam $\mathrm{NaCl}$ Dengan Konsentrasi

\begin{tabular}{cccll}
\hline \multicolumn{2}{c}{ Perlakuan } & \multicolumn{3}{c}{ Garam NaCl } \\
\cline { 2 - 5 } & $2,5 \%$ & $5 \%$ & $7,5 \%$ \\
\hline \multirow{2}{*}{ Daun Jambu } & $2,5 \%$ & $75,07^{\mathrm{c}}$ & $77,87^{\mathrm{b}}$ & $80,47^{\mathrm{b}}$ \\
biji & $5 \%$ & $75,05^{\mathrm{c}}$ & $77,74^{\mathrm{bc}}$ & $85,3^{\mathrm{a}}$ \\
& $7,5 \%$ & $68,14^{\mathrm{d}}$ & $77,09^{\mathrm{c}}$ & $79,80^{\mathrm{b}}$ \\
\hline
\end{tabular}

Ket: Superskrip yang berbeda pada setiap kombinasi perlakuan menunjukkan perbedaan yang nyata $(\mathrm{P}<0,01)$ 
daun jambu biji 7,5\% + 2,5\% garam $\mathrm{NaCl}$, daun jambu biji 7,5\% + 5\% garam $\mathrm{NaCl}$, daun jambu biji 7,5\% + 7,5\% garam $\mathrm{NaCl}$ berbeda sangat nyata $(\mathrm{P}<0,01)$. Kadar air yang paling baik yaitu yang menggunkan daun jambu biji 2,5\% + 7,5\% garam $\mathrm{NaCl}$ (68,14\%). Menurut Wulansari (2020), menyatakan bahwa makin rendah kadar air, makin lambat pertumbuhan mikroorganisme berkembang biak, sehingga proses pembusukan akan berlangsung lebih lambat. Garam 2,5\% mampu membuka struktur protein sehingga tanin terikat dalam protein selama pemindangan. Novia et al. (2011) menyatakan bahwa garam dalam pengawetan berpengaruh terhadap protein telur sehingga terjadi interaksi garam dan protein yang mengakibatkan protein mengalami denaturasi yaitu perubahan pada struktur sekunder dan tersier. Kastaman et al. (2010), menyatakan bahwa tekstur telur asin akan semakin keras dengan berkurangnya kadar air.

\section{Kekuatan Gel}

Hasil analisis sidik ragam menunjukkan bahwa interaksi daun jambu biji dan garam $\mathrm{NaCl}$ memberikan pengaruh yang berbeda sangat nyata $(\mathrm{P}<0,01)$ terhadap kekuatan gel telur pindang.

Berdasarkan hasil uji BNJ untuk ragam interaksi menunjukkan bahwa nilai kekuatan gel dengan menggunakan daun jambu biji 2,5\% + 2,5\% garam $\mathrm{NaCl}$ berbeda tidak nyata $(\mathrm{P}>0,01)$ dengan daun jambu biji $2,5 \%+5 \%$ garam $\mathrm{NaCl}$, tetapi berbeda sangat nyata dengan daun jambu biji 2,5\% +7,5\% garam $\mathrm{NaCl}$. Kemudian untuk daun jambu biji $5 \%+2,5 \%$ garam $\mathrm{NaCl}$ dan daun jambu biji 5\% +5\% garam $\mathrm{NaCl}$, serta daun jambu biji $5 \%+7,5 \%$ garam $\mathrm{NaCl}$ berbeda sangat nyata $(\mathrm{P}<0,01)$. Selanjutnya daun jambu biji 7,5\% + 2,5\% garam $\mathrm{NaCl}$ berbeda sangat nyata $(\mathrm{P}<0,01)$ dengan daun jambu biji 7,5\% +5\% garam $\mathrm{NaCl}$ dan daun jambu biji 7,5\% +7,5\%

Tabel 3. Rataan Kekuatan Gel $\left(\mathrm{g} / \mathrm{cm}^{2}\right)$ Telur Pindang Yang Menggunakan Daun Jambu Biji (Psidium guanjava L) serta Garam $\mathrm{NaCl}$ Dengan Konsentrasi

\begin{tabular}{cllll}
\hline \multicolumn{2}{c}{ Perlakuan } & \multicolumn{3}{c}{ Garam NaCl } \\
\cline { 2 - 5 } & $2,5 \%$ & $5 \%$ & $7,5 \%$ \\
\hline \multirow{2}{*}{ Daun Jambu } & $2,5 \%$ & $19,66^{\mathrm{f}}$ & $20,58^{\mathrm{f}}$ & $28,18^{\mathrm{e}}$ \\
biji & $5 \%$ & $19,59^{\mathrm{f}}$ & $41,50^{\mathrm{d}}$ & $46,33^{\mathrm{c}}$ \\
\hline
\end{tabular}

Ket: Superskrip yang berbeda pada setiap kombinasi perlakuan menunjukkan perbedaan yang nyata $(\mathrm{P}<0,01)$ 
garam $\mathrm{NaCl}$. Lebih lanjut daun jambu biji $7,5 \%+5 \%$ garam $\mathrm{NaCl}$ berbeda tidak nyata (P>0,01) dengan daun jambu biji 7,5\% + 7,5\% garam $\mathrm{NaCl}$.Dapat disimpulkan hasil uji BNJ menunjukkan bahwa nilai kekuatan gel paling baik yaitu yang menggunakan daun jambu biji 7,5\% + 7,5\% garam $\mathrm{NaCl}$ mendapat nilai $70,47\left(\mathrm{~g} / \mathrm{cm}^{2}\right)$. Hal ini karena semakin tinggi nilai kekuatan gel, maka semakin kenyal telur pindang yang dihasilkan sehingga telur pindang yang dihasilkan memiliki kualitas yang terbaik. Perlakuan garam 7,5\% mampu merubah struktur protein menjadi terbuka dan mengikat air serta tanin yang membentuk matrik interaksi protein air dan tanin selama pemindangan. Gel dari protein berbentuk padat dan berkarakteristik seperti cairan yang merupakan agregasi protein di mana polimer berinteraksi membentuk matriks tersier. Thohari et al. (2020), menyatakan fraksi protein telur antara lain kompleks ovomucin-lysozyme dapat membentuk struktur gel telur. Garam $\mathrm{NaCl}$ mengikat air dan dapat menyebabkan jarak antara molekul protein semakin dekat sehingga interaksi antara molekul protein semakin kuat (Novia et al., 2011).

\section{pH}

Hasil analisis sidik ragam menunjukkan bahwa daun jambu biji dan garam $\mathrm{NaCl}$ memberikan pengaruh yang berbeda sangat nyata $(\mathrm{P}<0,01)$, tetapi untuk interaksinya berbeda tidak nyata $(\mathrm{P}>0,01)$ terhadap $\mathrm{pH}$ telur pindang.

Berdasarkan hasil uji BNJ menunjukkan bahwa $\mathrm{pH}$ telur pindang yang menggunakan daun jambu biji sebagai faktor A, pada perlakuan A1 (2,5\%) dan A2 $(5 \%)$ tidak berbeda nyata $(\mathrm{P}>0,01)$, tetapi berbeda nyata dengan A3 (7,5\%).

Dapat disimpulkan data hasil uji $\mathrm{BNJ}, \mathrm{pH}$ dengan daun jambu biji sebagai faktor A menunjukkan bahwa perlakuan A3

Tabel 4. Rataan pH Telur Pindang Yang Menggunakan Daun Jambu Biji (Psidium guanjava L) serta Garam $\mathrm{NaCl}$ Dengan Konsentrasi

\begin{tabular}{|c|c|c|c|c|c|}
\hline \multirow{2}{*}{\multicolumn{2}{|c|}{ Perlakuan }} & \multicolumn{3}{|c|}{ Garam $\mathrm{NaCl}$} & \multirow{2}{*}{ Rataan } \\
\hline & & $2,5 \%$ & $5 \%$ & $7,5 \%$ & \\
\hline \multirow{3}{*}{$\begin{array}{c}\text { Daun Jambu } \\
\text { biji }\end{array}$} & $2,5 \%$ & 6,73 & 6,79 & 6,95 & $6.82^{\mathrm{a}}$ \\
\hline & $5 \%$ & 6,76 & 6,78 & 6,90 & $6,80^{\mathrm{a}}$ \\
\hline & $7,5 \%$ & 6,60 & 6,64 & 6,88 & $6,70^{\mathrm{b}}$ \\
\hline Rataan & & $6,69^{b}$ & $6,73^{b}$ & $6,91^{\mathrm{a}}$ & \\
\hline
\end{tabular}

Ket: Superskrip yang berbeda pada antar baris dan antar kolom pada rataan yang sama menunjukkan perbedaan yang nyata $(\mathrm{P}<0,01)$ 
7,5\% yang terbaik menghasilkan $\mathrm{pH}$ 6,7, karena memiliki $\mathrm{pH}$ terendah dan dengan $\mathrm{pH}$ yang rendah akan menyebabkan telur menjadi lebih awet. Wulandari (2002), menyatakan bahwa pengawetan atau pengolahan telur akan menghasilkan nilai $\mathrm{pH}$ yang paling rendah serta peningkatan total bakteri yang paling rendah sehingga proses pembusukan telur dapat diperlambat. Nilai pH ekstrak daun jambu biji berkisar diantara 6,11-6,49. hal ini menunjukkan bahwa konsentrasi daun jambu biji bersifat asam.

Berdasarkan hasil uji BNJ menunjukkan bahwa $\mathrm{pH}$ telur pindang menggunakan garam $\mathrm{NaCl}$ sebagai faktor B, menunjukkan bahwa perlakuan B3 $(7,5 \%)$ berbeda nyata $(\mathrm{P}<0,01)$ dengan $\mathrm{B} 2$ $(5 \%)$ dan B1 (2,5\%). Lebih lanjut B2 (5\%) dan B1 (2,5\%) tidak berbeda nyata $(\mathrm{P}>0,01)$.

Dapat disimpulkan data hasil uji $\mathrm{BNJ}, \mathrm{pH}$ dengan garam $\mathrm{NaCl}$ menunjukkan bahwa perlakuan yang terbaik yaitu B1 $(2,5 \%)$ menghasilkan $\mathrm{pH}$ yang rendah yaitu 6,69. Hal ini disebabkan garam mampu mengikat air telur sehingga pHnya jadi rendah. Hal ini didukung bahwa garam $\mathrm{NaCl}$ mampu mengikat air dan dapat menyebabkan jarak antara molekul protein semakin dekat sehingga interaksi antara molekul protein semakin kuat (Novia et al., 2011).

\section{KESIMPULAN}

Berdasarkan hasil penelitian dan pembahasan maka disimpulkan bahwa yang terbaik untuk sifat fisik dan kimia telur pindang yaitu $7,5 \%$ daun jambu biji (Psidium guanjava L) dan 7,5\% garam $\mathrm{NaCl}$

\section{DAFTAR PUSTAKA}

Agustina, N., T. Imam, dan D. Rosyidi. 2013. Evaluasi sifat putih telur ayam pasteurisasi ditinjau dari $\mathrm{pH}$, kadar air, sifat emulsi dan daya kembang angel cake. Jurnal Ilmu Peternakan 23(2): 6-13

AOAC, 2005. Official Methods of Analysis of The Association of Official Analytical Chemist. AOAC Inc., Washington.

Citra. 2014. Pengaruh Perebusan Telur Dengan Daun Jambu Biji Terhadap Komposisi Kimia Dan Mikrobia Telur Pindang. Skripsi. Ilmu dan Industri Peternakan. Universitas Sumatra Utara. Medan.

Dewi, S.U., P.Y. Saryana dan Nurjannah, R. 2013. Ekstraksi dan zat karakterisasi zat warna alami dari daun jambu biji serta uji potensinya sebagai pewarna tekstil. Jurnal FMIPA UNY. 10(4): 14-15.

Ernawati T., L. Ch. M. Karisoh., R. Hadju, dan S.E Siswosubroto. 2019. Pengaruh konsentrasi larutan daun jambu biji (Psidium guanjava $L$ ) dan lama perendaman terhadap kualitas telur ayam ras. Jurnal Zootec 39(2): 241-248. 
Kastaman, R., Sudaryanto, dan B. H. Nopianto. 2010. Kajian proses pengasinan telur metode reverse osmosisi pada berbagai lama perendaman. Jurnal Teknologi Industri Pertanian. 19(1): 30-39

Nasikin, M., F. J. Nangoy, C. L. K. Sarayar, dan M. H. M. Kawatu. 2015. Pengaruh subtitusi sebagian ransum dengan tepung tomat (Solanum Lycopersicum L) terhadap berat telur, berat kuning telur, dan massa telur ayam ras. Jurnal Zootek. 35(2): 225-234.

Nastiti, D. 2007. Kadar tanin dan kecernaan in vitro telur pindang dengan lama perebusan yang berbeda. Skripsi. Fakultas Peternakan. Institut Pertanian Bogor.

Novia, D., S. Melia, dan N. Z. Ayuza. 2011. Kajian suhu pengovenan terhadap kadar protein dan nilai organoleptik telur asin. Jurnal Peternakan 8(2): 70-76.

Nuruzakiah, H. Rahmatan, dan D. Syafrianti. 2016. Pengaruh konsentrasi garam terhadap kadar protein dan kualitas organoleptik telur bebek. Jurnal Peternakan 1(1): $1-9$

Richard, S. T., I. K Suada, dan M. D. Rudyanto. 2014. Pengawetan telur ayam ras dengan pencelupan dalam ekstrak air kulit manggis pada suhu ruang. Jurnal Indonesia Medicus Veterinus. 3(4): 310-316.

Samaludin, M. Wijaya, dan Kadirman. 2019. Daya terima telur pindang dengan penambahan bubuk daun jambu biji (Psidium guanjava Linn). Jurnal Pendidikan Teknologi Pertanian 5(1): 49-55
Steel, R. G. D. dan J. H. Torrie. 1991. Prinsip dan Prosedur Statistika. Diterjemahkan oleh Bambang Sumantri. PT. Gramedia Pustaka Utama. Jakarta

Suharyanto, N., B. Sulaiman, C. K. N. Zebka, I. I. Arief. 2016. Kualitas fisik, mikrobiologis, dan orgaoleptik telur konsumsi yang berbedar di sekitar kampus IPB, Darmaga, Bogor. Jurnal Ilmu Peternakan dan Teknologi Hasil Ternak 4(2): 275-279.

Sukma, A.W., A. Hintono, dan B.E Setiani. 2012. Perubahan mutu hedonik telur asin sangrai selama penyimpanan. Animal Agriculture Journal 1(1): 585-598

Thohari, I., F. Jaya, dan N. A. R. Ajeng. 2020. Pengaruh penambahan asam asetat terhadap sifat fungsional albumen telur itik. Jurnal Teknologi Hasil Peternakan, 1(1): 25-35

Titirloloby, E. 2006. Kualitas Telur Puyuh Pindang Yang Menggunakan Konsentrasi Garam $(\mathrm{NaCl})$ berbeda dan lama penyimpanan pada suhu kamar. Skripsi. Fakultas Peternakan. Universitas Sam Ratulangi.

Umar, R. Z. 2017. Karakteristik fisik dan fungsional telur konsumsi yang difermentasi dengan bakteri lactobacillus plantarum pada suhu dan lama inkubasi berbeda. Skripsi. Fakultas Peternakan. Universitas Hasanudin Makasar.

Wulandari, Z. 2002. Sifat Organoleptik, sifat fisiko-kimia dan total mikroba telur itik hasil penggaraman dengan tekanan. Tesis. Program Pascasarjana Institut Pertanian Bogor 
Wulansari, S. 2020. Formulasi daun jambu biji (Psidium guanjava L) terhadap karakteristik fisikokimia dan organoleptik telur pindang. Jurnal Teknologi Pangan dan Hasil Pertanian 15(1): 1-4 